\title{
The Effect of Mixed-Fruit Juice on Uterine Contractions and Cervical Dilatation During the First Stage of Delivery
}

\author{
Bellia Loranthifolia Martasari, ${ }^{1}$ Wisnu Cahyadi, ${ }^{2}$ Gaga Irawan Nugraha, ${ }^{3}$ Farid Husin, ${ }^{4}$ \\ Hadi Susiarno, ${ }^{5}$ Yudi Mulyana Hidayat, ${ }^{5}$ Mieke Hemiawati Satari ${ }^{6}$ \\ ${ }^{1}$ Midwifery Master Study Program, Faculty of Medicine, Universitas Padjadjaran, Bandung, Indonesia, \\ ${ }^{2}$ Department of Food Technology, Faculty of Engineering, Universitas Pasundan, Bandung, Indonesia, \\ ${ }^{3}$ Department of Medical Nutrition Science, ${ }^{4}$ Department of Public Health, ${ }^{5}$ Department of Obstetrics \\ and Gynecology, Faculty of Medicine, Universitas Padjadjaran, Bandung, Indonesia, \\ ${ }^{6}$ Department of Dentistry, Faculty of Dentistry, Universitas Padjadjaran, Bandung, Indonesia
}

\begin{abstract}
Energy imbalance in delivery can inhibit the action of glycolytic enzymes and interfere with chemical reactions in muscle cells. These nuisances may interfere with uterine contractions that obstruct cervical dilatation. Therefore, mothers require a nutritional alternative which is practical, generates energy quickly and supplies glucose needed for uterine contractions. These can be fulfilled with a mixed-fruit juice beverage. Mixed-fruit juice consists of fruits, Tunisian dates, honey, and red beans. This study aims to analyze the effect of the mixed-fruit extract on uterine contraction and cervical dilatation during the first stage of delivery. This study used a randomized controlled trial design. The target population was all the mothers who would give birth in Bandung city in March-April 2017. The samples of this study were the gravida <4 who would give birth at the Pelayanan Obstetri Neonatal Emergensi Dasar/PONED (Basic Emergency Obstetric and Neonatal Care/BEONC) Puskesmas (Public Health Center) Ibrahim Ajie, Puter, Garuda, Pagarsih, and Padasuka, consisting of 30 subjects as the treatment group and other 30 subjects as the control group. Uterine contractions and cervical dilatation were measured clinically and recorded on partograph. The analysis of data was done using the chi-square test, independent t test, and Mann-Whitney test. The results showed that there was the effect of mix-juice on the frequency, the duration and the intensity of uterine contractions and cervical dilatation with $\mathrm{p}$ value $<0.05$ and relative risk (RR) values respectively of $1.3,3.3,2.6$, 1.7. In conclusion, consuming mixed-fruit juice during the first stage of delivery give an impact on the progress of uterine contractions and cervical dilatation.
\end{abstract}

Key words: Cervical dilatation, mixed-fruit juice, uterine contractions

\section{Pengaruh Pemberian Minuman Mix Juice terhadap Kontraksi Uterus dan Pembukaan Serviks Selama Kala I Persalinan}

\begin{abstract}
Abstrak
Ketidakseimbangan energi saat persalinan dapat menghambat kerja enzim glikolitik dan mengganggu reaksi kimia dalam sel otot sehingga dapat menghambat kontraksi otot dan pembukaan serviks. Perlu alternatif nutrisi ibu bersalin yang praktis, cepat menghasilkan energi, dan memberikan asupan glukosa yang dibutuhkan untuk kontraksi uterus dalam bentuk minuman mix juice. Mix juice ini mengandung buah-buahan, kurma tunisia, madu, dan kacang merah. Penelitian ini bertujuan menganalisis pengaruh pemberian minuman mix juice terhadap kontraksi uterus dan pembukaan serviks selama kala I persalinan. Penelitian ini menggunakan desain randomized controlled trial. Populasi target adalah semua ibu yang akan melahirkan di Kota Bandung pada bulan MaretApril 2017. Sampel dalam penelitian ini adalah gravida < 4 yang akan melahirkan di Puskesmas Pelayanan Obstetri Neonatus Emergensi Dasar (PONED) Ibrahim Ajie, Puter, Garuda, Pagarsih, dan Padasuka, yaitu 30 subjek pada kelompok perlakuan dan 30 subjek pada kelompok kontrol. Kontraksi uterus dan pembukaan serviks diukur secara klinis dan dicatat pada partograf. Analisis data menggunakan uji chi-kuadrat, uji t independen, dan Uji MannWhitney. Hasil penelitian didapatkan pengaruh pemberian minuman mix juice terhadap frekuensi, lama dan intensitas kontraksi uterus, serta pembukaan serviks dengan nilai $\mathrm{p}<0,05$ dan nilai RR masing-masing sebesar 1,3; 3,$3 ; 2,6 ; 1,7$. Simpulan, pemberian minuman mix juice selama kala I persalinan berpengaruh terhadap kemajuan kontraksi uterus dan pembukaan serviks.
\end{abstract}

Kata kunci: Kontraksi uterus, minuman mix juice, pembukaan serviks

Received: 30 August 2017; Revised: 26 April 2019; Accepted: 29 April 2019; Published: 30 April 2019

Correspondence: Bellia Loranthifolia Martasari. Jln. Duren Raya No.008 Blok VI Perumnas Subang RT 036/RW oo8, Subang, West Java, Indonesia. Phone: (+62260) 412973. Mobile: +6281221897712. E-mail: mail.bellia@gmail.com 


\section{Introduction}

Delivering baby is the process of significant energy consumption which is regulated by the complex nervous system and hormonal response. ${ }^{1}$ Hormonal and metabolic changes along with physical and psychological adjustments during delivery can cause energy imbalance (glucose homeostatic disorder) and mental stress that can cause fatigue in delivery processes. The process of giving birth influenced by the power factor (power or uterus contractions), the birth canal (passage or cervix dilatation), and fetal factors (passenger or the move down of head). Inadequate uterine contractions and cervical dilatation can be affected by physical and psychological factors, including lack of energy supply, dehydration, ketoacidosis, and physical and mental fatigue. ${ }^{2-4}$

Inadequate uterus contractions and cervical dilatation can elevate the occurrence of prolonged delivery that can increase maternal and neonatal mortality and morbidity. According to the 2012 Indonesia Demographic and Health Survey (IDHS), the rates of prolonged labor were $35 \% .^{5}$ Research conducted by the National Institutes of Health in San Francisco in 2014 showed that $13.9 \%$ of nulliparae had a prolonged second stage and $31 \%$ of them experienced over 2 hours of stage. ${ }^{6}$

Glucose is the primary metabolic substrate used by the uterus. ${ }^{2}$ Lack of energy supply in the form of glucose will cause fatigue of the uterine muscles. ${ }^{3}$ If fatigue occurs, lactic acid accumulates that makes the glycolytic enzymes work is inhibited, interferes chemical reactions in muscle cells, and hampers the release of $\mathrm{Ca}^{2+}$ ions, causing muscle contraction to be weakened or disrupted. A study conducted by Ebrahimzadeh et al. ${ }^{3}$ confirms that fatigue causes changes in the pattern of uterine contractions and affects the progress of the delivery. Several factors influence this including metabolite production, changes in energy level and energy-producing enzymes, psychological conditions, and environmental factors. ${ }^{1,4}$

The production of metabolites and changes in the energy level of the mother during delivery fulfilled with adequate nutrition. Unfortunately, based on the results of a preliminary study on 30 mothers during delivery it was found that $87 \%$ of mothers still wanted to consume food at the first latent stage and after entering the active phase, it dropped to $40 \%$ due to the more frequent pain. In the second stage of delivery, only $6 \%$ of mothers consumed food and only in liquid form. The average number of calories that a mother consumed was only $30 \mathrm{kcal} / \mathrm{hour}$. Although the mother can cope with her childbirth without food, this may bring detrimental effect on the delivery process to both mother and baby, such as prolonged delivery and delivery with actions. 7,8

Insufficient maternal energy needs during delivery will cause fatigue. ${ }^{3}$ Malin et al. $^{8}$ and Rahmani et al. ${ }^{9}$ recommend energy requirements during delivery, namely $50-100 \mathrm{kcal} /$ hour to prevent fatigue. Nutritional intakes prioritized for fulfilling the energy needed for uterine contraction. The types of nutrients required are kinds of food that provide energy, hydrate and prepare for the postpartum period. ${ }^{10}$ Ideal nutrition for maternity must have a similar quality, high carbohydrates, high calories, and low residue, as well as in the forms of liquid or semi-solid. The reason is that in the current stage of delivery there is an inhibition of gastric emptying. Thus, if given solid food the nutrients cannot be adequately absorbed. ${ }^{2,7}$

During maternity, mothers do not only need one nutrient to increase nutritional value and to adjust for the calories needed, but a combination of various ingredients (mixed-fruit juice) to get all the benefits. In this study, mixed-fruit juice consists of Tunisian dates, honey, boiled, dried red beans and fruits such as mangoes, oranges, and red guava. These ingredients chose because they contain monosaccharides in the forms of fructose and glucose which can be quickly transported into the blood, promptly produce energy, and strengthen people who are sick or who are experiencing extreme fatigue..$^{11,12}$

Glucose available in the blood is an energy substrate used at the beginning of delivery (3-6 $\mathrm{cm}$ dilatation) while glycogen in the muscle used during further stages $(7-10 \mathrm{~cm}$ dilatation and during the birth process). The longer the delivery processes, the lower is the glucose stored..$^{13}$ High glucose load during delivery causes the mother to require additional nutritional alternative that has good taste, is practical, has sufficient calorie needs as well as produces energy quickly. Therefore, it is necessary to make a mixed-fruit juice which is expected to be able to give impact on the adequate uterine contractions and progress of cervical dilatation during the first stage of delivery.

\section{Methods}

The method used in this study was a randomized 
controlled trial (RCT). This study was conducted by measuring uterine contractions and cervical dilatation during the first stage of labor from both the treatment and the control groups. The treatment group consumed a mixed-fruit juice, while the control group had the freedom to eat and drink anything. The amount of intake in the two groups evaluated per 2 hours and the number of calories consumed calculated during the delivery process. This study conducted at five Pelayanan Obstetri Neonatal Emergensi Dasar (PONED) or the Basic Emergency Obstetric and Neonatal Care (BEONC) puskesmas (public health center) in Bandung city. They were Public Health Center Ibrahim Ajie, Puter, Garuda, Pagarsih, and Padasuka. The target population in this study were all mothers who would give birth in Bandung city.

Meanwhile, the accessible population in this study were the pregnant women with gravida $<4$ who would give birth at the PONED public health centers in Bandung city. Then the samples were taken using block randomization, specifically through permutation block. The number of samples needed was 30 subjects for each of the treatment group and the control group taken from March-April 2017.

The inclusion criteria were mothers who would give birth at the age of 20-35 years with gravida <4 came when in the latent phase, had average body mass index (BMI) before pregnancy of $18.5^{-24.9} \mathrm{~kg} / \mathrm{m}^{2}$, were in a-term, single, and healthy pregnancies. Besides, the exclusion criteria included complications during pregnancy, complications during labor, specific food allergies, history of gastritis, and having metabolic disorders. Further, the drop-out criteria were not consuming drinks as much as $100 \mathrm{kcal} /$ hour, labor with actions, his abnormalities, fetal distress, and the prolonged first stage of the delivery $>12$ hours in primigravida and $>8$ hours in multigravida.

The procedure for making mixed-fruit juice began with determining the compositions of the nutrient contents of each ingredient, then formulating and conducting experiment until the three formulas. An organoleptic test was carried out to these three formulas to find out the best one. Afterward, two flavors created, guava and mango-finally, both variants facing the quality test, the microbial and Escherichia coli test.

Monitoring of the amount of mixed-fruit juice spent in the treatment group as well as the food and beverages consumed by the mothers in the control group during the first stage of labor was carried out by the enumerator. The results of the monitoring recorded in the specific form. Uterine contractions were measured every 30 minutes with manual palpation. The number, strength, and duration of contractions for 10 minutes were counted and observed using a partograph. The length of uterine contractions was also found using a stopwatch. Further, cervical dilatation was measured every four hours and or based on the theory of progression of cervical dilatation using the vaginal toucher and was observed using the partograph. Lastly, the data analysis of this study was implemented using the chi-square test, independent $\mathrm{t}$ test, and the Mann-Whitney test. This study aims to analyze the effect of the mixedfruit extract on uterine contraction and cervical dilatation during the first stage of delivery.

This study conducted after obtaining the feasibility permit from the Health Research Ethics Committee of the Faculty of Medicine, Universitas Padjadjaran Bandung with No. 262/ UN6.C10/PN/2017. This study applied three basic principles of research ethics, namely respect to a person, beneficence and nonmaleficence, and justice.

\section{Results}

The quality test analysis of mixed-fruit juice beverages was carried out at the Food Technology Laboratory of Universitas Pasundan Bandung with the following results (Table 1). Mostly the quality of the products met the beverage quality standards for maternity and Standar Nasional Indonesia/SNI (Indonesian National Standards) 01-7148-2005. However, the contents of proteins are lower while the carbohydrates are higher than the rules.

Both research groups similar in terms of age, occupation, BMI, gravida, cervical dilatation at the arrival time and anxiety levels explained in detail in Table 2. The results of $t$ test show that there were no significant differences ( $>0.05$ ) between the treatment and the control groups in terms of age, occupation, BMI, gravida, cervical dilatation at the arrival time and anxiety levels.

The two research groups were compared in terms of uterine contractions and increased cervical dilatation during the first active stage was in Table 3 . Table 3 shows that there are significant differences $(p<0.05)$ between the group with mixed-fruit juice beverages and the group without mixed-fruit juice beverages in terms of 
Table 1 The Results of Quality Test Analysis of Mix Juice Beverages

\begin{tabular}{lccc}
\hline Test Type & $\begin{array}{c}\text { Guava Mix Juice } \\
\text { Variant }\end{array}$ & $\begin{array}{c}\text { Mango Mix Juice } \\
\text { Variant }\end{array}$ & $\begin{array}{c}\text { Quality Standards } \\
\text { (per 10o mL) }\end{array}$ \\
\hline Water (\%) & 76.60 & 77.20 & - \\
Ash (g) & 0.01 & 0.01 & Max. 1.1 \\
Fat (g) & 1.80 & 1.80 & Min. 0.6 \\
Protein (g) & 1.80 & 1.80 & $3.2-4.4$ \\
Carbohydrate (g) & 20.90 & 20.80 & Max. 4.4 \\
Calorie/energy (kcal) & 107.00 & 105.00 & Min. 65 \\
\hline
\end{tabular}

Table 2 Characteristics of the Research Subjects

\begin{tabular}{|c|c|c|c|}
\hline \multirow{2}{*}{ Characteristics } & \multicolumn{2}{|c|}{ Groups } & \multirow{2}{*}{ p Value } \\
\hline & Treatment $(n=30)$ & Control $(n=30)$ & \\
\hline \multicolumn{4}{|l|}{ Age (year) } \\
\hline $20-24$ & 11 & 9 & 0.149 \\
\hline $25-29$ & 11 & 6 & \\
\hline $30-35$ & 8 & 15 & \\
\hline $\mathrm{x}(\mathrm{SD})$ & $26.3(4.5)$ & $28.3(5.5)$ & \\
\hline Range & $20-35$ & $20-35$ & \\
\hline \multicolumn{4}{|l|}{ Occupation } \\
\hline Employed & 8 & 10 & 0.573 \\
\hline Unemployed & 22 & 20 & \\
\hline \multicolumn{4}{|c|}{ Body mass index $\left(\mathrm{kg} / \mathrm{m}^{2}\right)$} \\
\hline x (SD) & $21.2(1.8)$ & $21.6(1.8)$ & $0.407^{* *}$ \\
\hline Median & 21.2 & 21.6 & \\
\hline Range & $18.5^{-24.9}$ & $18.6-24.9$ & \\
\hline \multicolumn{4}{|l|}{ Gravida } \\
\hline Primigravida & 14 & 12 & 0.602 \\
\hline Multigravida & 16 & 18 & \\
\hline \multicolumn{4}{|c|}{ Cervical dilatation at arrival $(\mathrm{cm})$} \\
\hline 2 & 11 & 9 & 0.584 \\
\hline 3 & 19 & 21 & \\
\hline \multicolumn{4}{|l|}{ Levels of anxiety } \\
\hline None & 23 & 26 & 0.453 \\
\hline Low & 6 & 4 & \\
\hline Medium & 1 & $\mathrm{O}$ & \\
\hline
\end{tabular}

frequency, duration of uterine contractions, the intensity of uterine contractions, and cervical dilatation during the first active stage of labor. Also, mothers who did not get mixed-fruit juice beverages had higher risks on low frequency, duration, the intensity of contractions and cervical dilatation during the first stage of labor than those who got mixed-fruit juice beverages.

\section{Discussion}

The water levels in this mixed-fruit juice beverages were $76.6 \%$ (red guava variant) and $77.2 \%$ (mango variant). This was because the beverage products are mostly contained water. The levels of ash in the mixed-fruit juice beverages also met the quality standard of beverages. The higher 
Table 3 The Effect of Intervention on Uterine Contractions and Increased Cervical Dilatation

\begin{tabular}{|c|c|c|c|c|c|c|}
\hline \multirow{3}{*}{ Categories } & \multicolumn{4}{|c|}{ Groups } & \multirow{3}{*}{ p Value* } & \multirow{3}{*}{$\underset{(95 \% \mathrm{CI})}{\mathrm{RR}}$} \\
\hline & \multicolumn{2}{|c|}{ Control } & \multicolumn{2}{|c|}{ Treatment } & & \\
\hline & $\mathbf{n}=\mathbf{3 0}$ & $\%$ & $n=30$ & $\%$ & & \\
\hline \multicolumn{7}{|c|}{$\begin{array}{l}\text { Uterine contractions during } \\
\text { the first active stage }\end{array}$} \\
\hline \multicolumn{7}{|c|}{ Frequency (times) } \\
\hline $\mathrm{x}(\mathrm{SD})$ & \multicolumn{2}{|c|}{$4.2(0.4)$} & \multicolumn{2}{|c|}{$3.5(0.5)$} & & \\
\hline Median & \multirow{2}{*}{\multicolumn{2}{|c|}{$\begin{array}{c}4 \\
4-5\end{array}$}} & \multirow{2}{*}{\multicolumn{2}{|c|}{$\begin{array}{c}3 \\
3-4\end{array}$}} & $0011^{* *}$ & 1.30 \\
\hline Range & & & & & $0.011^{* * 2 *}$ & $(1.07-1.59)$ \\
\hline$<4$ & 30 & 100 & 23 & 77 & & \\
\hline$\geq 4$ & o & o & 7 & 23 & & \\
\hline \multicolumn{7}{|c|}{ Duration (seconds) } \\
\hline $\mathrm{x}(\mathrm{SD})$ & \multicolumn{2}{|c|}{$46.3(8.8)$} & \multicolumn{2}{|c|}{$40.0(5.4)$} & & \\
\hline Median & \multirow{2}{*}{\multicolumn{2}{|c|}{$\begin{array}{c}45 \\
31-66\end{array}$}} & \multirow{2}{*}{\multicolumn{2}{|c|}{$\begin{array}{c}38 \\
34-55\end{array}$}} & & \\
\hline Range & & & & & 0.000 & $(1.67-6.47)$ \\
\hline$\leq 40$ & 23 & 77 & 7 & 23 & & \\
\hline$>40$ & 7 & 23 & 23 & 77 & & \\
\hline \multicolumn{7}{|l|}{ Intensity } \\
\hline Weak & 18 & 60 & 7 & 23 & 0.004 & 2.571 \\
\hline Strong & 12 & 40 & 23 & 77 & & $(1.26-5.24)$ \\
\hline \multicolumn{7}{|c|}{$\begin{array}{l}\text { Increased cervical dilatation } \\
\text { (cm/hour) }\end{array}$} \\
\hline $\mathrm{x}(\mathrm{SD})$ & \multicolumn{2}{|c|}{$1.9(0.7)$} & \multicolumn{2}{|c|}{$1.4(0.7)$} & & \\
\hline Median & \multicolumn{2}{|c|}{1.9} & \multicolumn{2}{|c|}{1.3} & 0.039 & 1.73 \\
\hline Range & \multicolumn{2}{|c|}{$0.7-3.0$} & \multicolumn{2}{|c|}{$0.3-3.3$} & & $(1.00-2.97)$ \\
\hline$<2$ & 19 & 63 & 11 & 37 & & \\
\hline$\geq 2$ & 11 & 37 & 19 & 63 & & \\
\hline
\end{tabular}

${ }^{*}$ Chi-square test, ${ }^{* *}$ Fisher's exact test

the ash level in a food product, the worse is the quality of food products for the ash level reflects the level of cleanliness and purity of a material. ${ }^{14}$ At the same time, the fat contents in the mixedfruit juice beverages are higher than the standard level while the protein levels of the mixed-fruit juice beverages were lower than that from the SNI 01-7148-2005. However, this did not become an obstacle during this study because the fat and the protein levels in this study were not taken into account.

The carbohydrate levels in the mixed-fruit juice were higher than the standard of drink for pregnant women, because mothers in the labor process needed more glucose contained in high carbohydrates as the main source of nutrition in metabolism in the myometrium during labor. The longer the labor, the lower is the stored glucose.
Therefore, higher glucose intake is needed during labor. ${ }^{13}$

In this study, the research subjects from the treatment group and the control group had the same features including age, occupation, BMI, gravida, dilatation at the arrival time, and anxiety levels. The age and BMI of the respondents were almost similar; still in the reproductive age with a range of 20-35 years old and were in the healthy BMI category of $18.50-24.99 \mathrm{~kg} / \mathrm{m}^{2}$. Meanwhile, most of the research subjects from both groups were unemployed. Regarding the gravida, there was no significant difference between the treatment group and the control group because the gravida group respondents limited to the inclusion criteria, namely the gravida $<4$. Likewise, the cervical dilatation at the arrival time had also limited to the inclusion criteria, which 
was $<4 \mathrm{~cm}$. Last, the levels of anxiety between the two groups did not have a significant difference, that the levels of tension of the research subjects were homogeneous.

One of the factors that can affect the progress of labor is power (uterine contractions). The more adequate contractions of the smooth muscle of the uterus will result in the thinning and widening of the cervix progressively. ${ }^{8}$ One factor that can affect appropriate uterine contractions is nutrient intake. The results are following Abdel Ghani's ${ }^{15}$ research in 2012, showing that oral consumption of nutrients in the form of zam-zam water proved to have a significant effect on the frequency and duration of uterine contractions. The study showed the blood glucose levels maintained between groups. If the blood glucose level is low, it can result in the formation of ketones which can interfere uterine contractility.

During the delivery process highcarbohydrates, low-fat, and low-residue nutrients in the forms of liquid or semi-solid need to be easily absorbed. It also need to produce energy quickly that affect the structure and strength of uterine muscle contractions. ${ }^{2,7}$ The ingredients contained in the mixed-fruit juice beverages were safe to be consumed, and they contained carbohydrates (glucose) as an energy source in the myometrium. Carbohydrates are the primary energy source that can be digested by the human body and glucose contained in carbs is the primary energy source in the body because some organs in the body only use glucose. Carbohydrates contained in these mixed-fruit juice beverages were monosaccharide type. Monosaccharides absorbed by the intestine and cannot be hydrolyzed further into simple sugars. ${ }^{16}$

Once entered through the mouth, the carbohydrates in the mixed-fruit juice will go through a chemical digestion process, namely the digestive process aided by enzymes. The tongue pushes the drink towards the pharynx then passes the esophagus. The esophageal muscles contract and drive the liquid into the stomach. The stomach muscles contract to stir up the liquid, break it mechanically, and mix it with gastric juice and then pass it to the small intestine little by little. Food in the form of carbohydrates will be digested by amylase pancreas to be disaccharides. The disaccharides are broken down by the disaccharidases into monosaccharides, namely the glucose. This glucose absorption occurs in intestinal absorption. After being absorbed by the villi of the small intestine, glucose, watersoluble vitamins, amino acids, and minerals will then be carried by blood vessels and circulated throughout the body, including muscles that are actively contracting like the uterine muscles during delivery process. ${ }^{1,8}$ In other words, glucose is the primary fuel for muscle contractions. ${ }^{17}$

The mean frequency and duration of uterine contractions during the first active stage in the treatment group were higher than the control group, and statistics showed significant differences between the two groups. There was also a considerable difference between the treatment and the control group concerning contraction intensity. The results showed the success of giving mixed-fruit juice beverages. The high carbohydrates contained in the mixedfruit juice beverages, which were equal to 83 $\mathrm{kcal} /$ hour that could be a source of nutrition and the primary source of energy for myometrial contraction..$^{2,7}$

Muscle contractions during strenuous activities are highly dependent on the availability of carbohydrates as energy because of the ability of the muscles to use fat as limited energy. If the availability of glucose is lacking, it will cause lactic acid to accumulate, which will cause the $\mathrm{pH}$ blood and muscles to decrease, the work of glycolytic enzymes inhibited, disrupt chemical reactions in muscle cells, and inhibit the release of $\mathrm{Ca}^{2+}$ ions and eventually cause impaired muscle contraction. Therefore, for doing endless activities for more than one hour, it is recommended to increase the absorption of glucose from outside in addition to relying on reserves from the body. ${ }^{18}$

A proper contraction will affect the progress of the delivery process. Rahmani et al.'s ${ }^{9}$ study found that low-risk women with $3-4 \mathrm{~cm}$ cervical dilatation with the intake of dates or orange juice during the active delivery process could reduce the duration of the second stage of the delivery process. The uterine contractions occur in the dynamic segment that causes the uterine retraction and fetal pushing to the bottom of the pelvis. Retraction and the moving down of fetal head cause the stretching of the lower uterine segment, thinning and opening of the cervix. Regular uterine smooth muscle contractions result in progressive thinning and widening of the uterus which can affect the progress of the delivery process. Myometrial contractions continue to increase with the development of the delivery process due to a positive feedback cycle 
involving oxytocin and prostaglandin. Oxytocin is a peptide secreted by the posterior pituitary which can change transmembrane ion currents in myometrial smooth muscle cells to produce uterine contractions continuously. ${ }^{19}$

In this study, the phytochemical content from each mixed-fruit juice ingredients was not examined. Hence it could not be explained in detail. Therefore, further research is required to explore the effect of the phytochemical content of mix juice ingredients on the progress of the delivery process, especially on uterine contractions and cervical dilatation.

\section{Conclusion}

Mixed-fruit juice beverages during the delivery process can affect uterine contractions and cervical dilatation during the active stage of the delivery process.

\section{Conflict of Interest}

All authors declare that there was no conflict of interest in this article.

\section{Acknowledgements}

We would like to thank the Food Analysis Delivery Laboratory of Universitas Pasundan, Bandung, and the Food Technology of Nutrition Department, Bandung Health Polytechnic of Ministry of Health, as well as all the experts who have helped in the process of making the mix juice beverages.

\section{References}

1. Tzeng YL, Chao YMY, Kuo SY, Teng YK. Childbirth-related fatigue trajectories during labour. J Adv Nurs. 2008;63(3):240-9.

2. American College of Nurse-Midwives. Providing oral nutrition to women in labor. J Midwifery Women's Health. 2008;53(3):276-83.

3. Ebrahimzadeh S, Golmakani N, Kabirian M, Shakeri MT. Study of correlation between maternal fatigue and uterine contraction pattern in the active phase of labour. J Clin Nurs. 2012;21(11-12):1563-9.

4. Cinar S, Çinar ND, Görpelioglu S, Sözeri CU. Prepartum and postpartum acute fatigue and the influencing factors. RBPS.
2007;20(1):60-4.

5. Statistics Indonesia; National Population and Family Planning Board; Ministry of Health of Republic of Indonesia; MEASURE DHS, ICF International. The 2012 Indonesia demographic and health survey. Jakarta: Statistics Indonesia (Badan Pusat StatistikBPS); 2013.

6. Laughon SK, Berghella V, Reddy UM, Sundaram R, Lu Z, Hoffman MK. Neonatal and maternal outcomes with prolonged second stage of labor. Obstet Gynecol. 2014;124(1):57-67.

7. Maharaj D. Eating and drinking in labor: should it be allowed? Eur J Obstet Gynecol Reprod Biol. 2009;146(1):3-7.

8. Malin GL, Bugg GJ, Thornton J, Taylor MA, Grauwen N, Devlieger R, et al. Does oral carbohydrate supplementation improve labour outcome? A systematic review and individual patient data meta-analysis. BJOG. 2016;123(4):510-7.

9. Rahmani R, Khakbazan Z, Yavari P, Granmayeh M, Yavari L. Effect of oral carbohydrate intake on labor progress: randomized controlled trial. Iran J Public Health. 2012;41(11):59-66.

10. Ozkan SA, Kadioglu M, Rathfisch G. Restricting oral fluid and food intake during labour: a qualitative analysis of women's views. IJCS. 2017;10(1):235-42.

11. Bogdanov S, Jurendic T, Sieber R, Gallmann P. Honey for nutrition and health: a review. J Am Coll Nutr. 2008;27(6):677-89.

12. Mariyam P, Mary V. Nutritional analysis (macronutrients, potassium and iron content) of four palm date varieties (Phoenix dactylifera L.) and study of consumption pattern among Muslim and Maharashtrian community (2014). JFPB. 2015;3(1):9.

13. Benfield RD, Newton ER, Tanner CJ, Heitkemper MM. Cortisol as a biomarker of stress in term human labor: physiological and methodological issues. Biol Res Nurs. 2014;16(1):64-71.

14. Herawati H. Penentuan umur simpan pada produk pangan. JPPP. 2008;27(4):124-30.

15. Abdel Ghani RM. Effect of zam zam water intake during labor on maternal and neonatal outcome: a randomized controlled trial. Acad Res Int. 2012;2(3):58-69.

16. Asif HM, Akram M, Saeed T, Khan MI, Akhtar $\mathrm{N}$, Rehman RU, et al. Carbohydrates. Int Res 
J Biochem Bioinfor. 2011;1(1):001-5.

17. Rodwell VW, Bender DA, Botham KM, Kennelly PJ, Weil PA. Biokimia Harper. $3^{\text {th }}$ Edition. Jakarta: EGC Penerbit Buku Kedokteran; 2017.

18. Arrafif U, Noordia A. Efektivitas kombinasi minuman sari buah pisang dan air kelapa muda terhadap daya tahan anaerob. JKO. 2017;5(1):58-65.

19. Indriyanti A, Sujatno M, Soekandar AW. Pengaruh ekstrak etanol buah mahkota dewa \{Phaleria macrocarpa (Scheff) Boerl\} per oral terhadap kontrakstilitas uterus mencit model gravida. GMHC. 2016;4(1):60-5. 